\title{
THE STRUCTURAL ANALYSIS OF PRIMARY DISABILITY OF EMPLOYABLE POPULATION IN FERGANA REGION
}

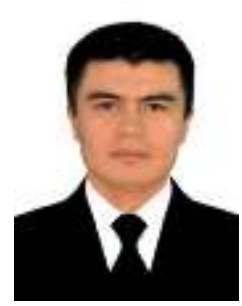

Matkhoshimov Nodirjon Soyibjonovich

Basic doctoral student - Tashkent medical academy

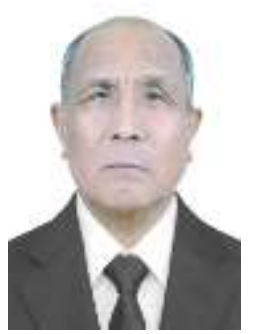

Isakov Erkin Ziyoyevich

Department of Hygiene and public health of

Fergana branch of Tashkent medical academy,

Doctor of medical sciences

Article DOI: https://doi.org/10.36713/epra2485

\begin{abstract}
The article dealt with the structural analysis of primary disability of employable population in Fergana region. The main causes of disability have been highlighted by classes of diseases and their distribution by survey. The specific position of the primary disability of employable population have been analyzed by place of residence, age and gender groups of this contingent.
\end{abstract}

KEY WORDS: disability of employable age, level, specific position, class, diseases, analysis, dynamics, the spread, structure.

\section{INTRODUCTION}

The actuality of the problem of disability and disable people is determined by a large number of people in this category in the social structure of society $[1,3,4,7,8]$. According to UN experts, people with disabilities account for $10 \%$ of the total population of the Earth [2].

S.N. Puzin $(2006,2008)$ noted that the disability indicator characterizes social ill-being of population, reflects social maturity, economic viability, moral development of society and violation of relationship between disabled person and society $[5,6]$.

One of the priority directions of the state health policy is preventing and strengthening the health of employable population, on which the country's socio-economic development depends. The disability of employable population is an actual problem for not only public health and social protection authorities, but also for executive and 
legislative bodies at all levels of the government hierarchical vertical [3].

At present, disability among employable population is one of the most urgent public health problems, which directly affects socio-economic development of the country [4].

However, this problem has been insufficiently studied, and comprehensive in-depth study the formation of disability of employable population in the Republic of Uzbekistan, particularly in Fergana region, has not been carried out. Therefore, the condition of this problem is one of the main characteristics of the country's public health and social well-being.

The aim of the research is to study the structure of primary disability of employable population in Fergana region.

\section{MATERIALS AND THE RESEARCH METHODS}

Object of the research is the set of first registered disabled people of employable age in Fergana region.

The research is continuous. The study volume amounted to 4013 people of all newly registered disabled people of working age in 2017.
The material for the study was the official statistical data of the Republican Inspectorate of Medical and Social Expertise under the Ministry of Health Care and the reports of the State Statistics Committee of the Republic of Uzbekistan.

The unit of observation is the first recognized disabled person of employable age.

\section{RESULTS AND DISCUSSION}

The number of newly recognized disabled adults in Fergana region amounted to 4,013 people in 2017.

The distribution of primary disability by age groups of employable population observed as follows: primary disabled people aged 15-are 562 people $(14.0 \%)$; in the age group of $17-19-70$ $(1.7 \%)$; in age group of 20-24 - $173(4.3 \%)$; in age group of $25-29-280(7.0 \%)$; in age group of $30-34$ $380(9.5 \%)$; in the age group of $35-39-410(10.2 \%)$; in the age group of 40-44 - $446(11.1 \%)$; in the age group of 45-49 - $501(12.6 \%)$; in age group of 50-54 - $652(16.2 \%)$; in age group of 55-59 - 539 (13.4\%). (Figure 1.)

Figure 1. Distribution of primary recognized disablity of the employable people by age groups in 2017

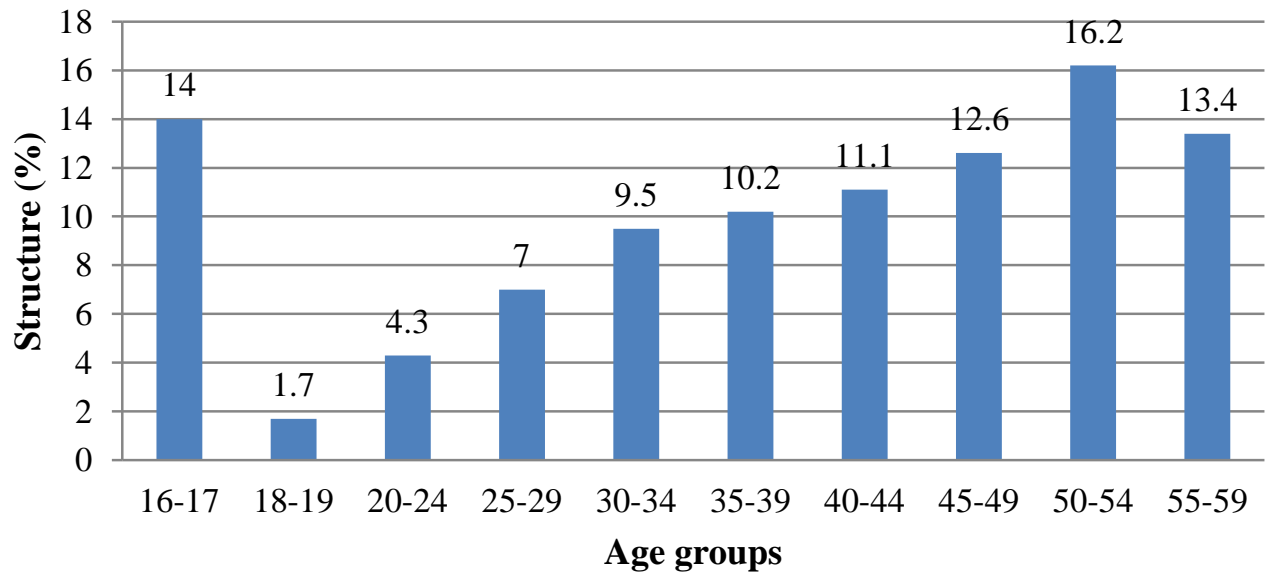

Figure 1 shows, the number of primary disabled people among the whole employable population was 562 people $(14.0 \%)$ in the age group of 16-17, and subsequently there is a sharp decrease in the proportion of primary disability in the age group of $18-19$ and equals 70 people $(1.7 \%)$. In our opinion, an increase in the proportion of disabilities in the age groups of 16-17 may be due to subjective factors, because children with disabilities under 15 get disability benefit despite the disability level.
From 16 age, the disability level are taken into account for receiving benefit.

For the above-mentioned reason, among children of 16-17 age, the appeal to medical reexamination is sharply increased for determining disability level.

Consequently, the proportion of people with disabilities sharply decreased between 18-19 ages, because the majority population of this age group, when they were aged 16-17, had already been reexamined for disability and the extensive indicator of 
disability gradually increases between age group of 50-54.

The highest proportion of primary disability among employable population are the disabled people of 50-54 age and 55-59, respectively $16.2 \%$

and $13.4 \%$. This may be explained by getting disability pension on the eve of retirement age.

It should be noted, it is also characteristic of the population by place of residence (urban and rural areas) and gender characteristics of the population in Fergana region (Table 1).

Table 1

Age and gender distribution of primary registered disabled people by place of residence in Fergana region for 2017

\begin{tabular}{|c|c|c|c|c|c|c|c|c|c|c|}
\hline \multirow[b]{4}{*}{$\begin{array}{c}\text { Age } \\
\text { groups }\end{array}$} & \multirow{3}{*}{\multicolumn{2}{|c|}{ Total number }} & \multicolumn{8}{|c|}{ Including } \\
\hline & & & \multicolumn{4}{|c|}{ By place of residence } & \multicolumn{4}{|c|}{ By sex } \\
\hline & & & \multicolumn{2}{|c|}{ Urban } & \multicolumn{2}{|c|}{ Rural } & \multicolumn{2}{|c|}{ Male } & \multicolumn{2}{|c|}{ Female } \\
\hline & 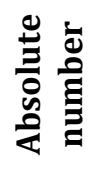 & $\partial^{0}$ & 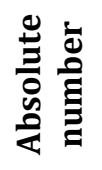 & $\partial^{0}$ & 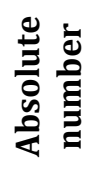 & $a^{e}$ & 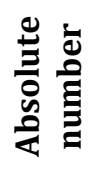 & $\partial^{0}$ & 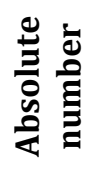 & $\partial^{0}$ \\
\hline $15-16$ & 562 & 14,0 & 208 & 13,5 & 354 & 14,4 & 316 & 13,0 & 246 & 15,5 \\
\hline $18-19$ & 70 & 1,7 & 23 & 1,5 & 47 & 1,9 & 40 & 1,6 & 30 & 1,9 \\
\hline $20-24$ & 173 & 4,3 & 57 & 3,7 & 116 & 4,7 & 117 & 4,8 & 56 & 3,5 \\
\hline $25-29$ & 280 & 7,0 & 88 & 5,7 & 192 & 7,8 & 170 & 7,0 & 110 & 6,9 \\
\hline $30-14$ & 380 & 9,5 & 137 & 8,8 & 243 & 9,9 & 193 & 8,0 & 187 & 11,8 \\
\hline $35-39$ & 410 & 10,2 & 149 & 9,6 & 261 & 10,6 & 211 & 8,7 & 199 & 12,5 \\
\hline $40-44$ & 446 & 11,1 & 180 & 11,6 & 266 & 10,8 & 240 & 9,9 & 206 & 13,0 \\
\hline $45-49$ & 501 & 12,6 & 192 & 12,4 & 309 & 12,5 & 244 & 10,1 & 257 & 16,2 \\
\hline $50-54$ & 652 & 16,2 & 280 & 18,1 & 372 & 15,1 & 355 & 14,6 & 297 & 18,7 \\
\hline 55-59 & 539 & 13,4 & 233 & 15,1 & 306 & 12,4 & 539 & 22,2 & - & - \\
\hline Totally & 4013 & 100,0 & 1547 & 100,0 & 2466 & 100,0 & 2425 & 100,0 & 1588 & 100,0 \\
\hline
\end{tabular}

Particular interest rises in the analysis of the disability distribution by class of diseases caused disability.
The structure of primary disability among people of employable age have been studied in Fergana region for 2017. (Table 2) 
Table 2

The structure of primary disability of the employable people by class of diseases for 2017 considering the rank (\%)

\begin{tabular}{|c|c|c|c|c|}
\hline № & The class of diseases & 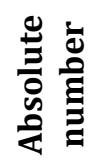 & ১ & 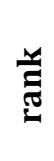 \\
\hline 1 & Mental disorder and behavioral disorder & 618 & 15,4 & 1 \\
\hline 2 & Malignant neoplasms & 524 & 13,1 & 2 \\
\hline 3 & Diseases of the nervous system & 482 & 12,0 & 3 \\
\hline 4 & Diseases of the blood circulatory system & 428 & 10,7 & 4 \\
\hline 5 & Traumas, intoxication and some other consequences of external factors & 325 & 8,1 & 5 \\
\hline 6 & Diseases of the digestive system & 316 & 7,9 & 6 \\
\hline 7 & Diseases of the musculoskeletal system and connective tissues & 250 & 6,2 & 7 \\
\hline 8 & $\begin{array}{l}\text { Diseases of the endocrine system, nutritional disorders, metabolic } \\
\text { disorders }\end{array}$ & 222 & 5,5 & 8 \\
\hline 9 & Eye diseases and appendages of eye & 181 & 4,5 & 9 \\
\hline 10 & $\begin{array}{l}\text { Congenital anomaly, (development defect), deformation and } \\
\text { chromosome disorders }\end{array}$ & 151 & 3,8 & 10 \\
\hline 11 & Tuberculosis & 114 & 2,8 & 11 \\
\hline 12 & Diseases of the urogenital system & 107 & 2,7 & 12 \\
\hline 13 & Diseases of the respiratory system & 106 & 2,6 & 13 \\
\hline 14 & Diseases of ear and mastoid bone & 42 & 1,0 & 14 \\
\hline 15 & $\begin{array}{l}\text { Blood and hemopoietic organs diseases, individual disorders involving } \\
\text { immune mechanism }\end{array}$ & 42 & 1,0 & 15 \\
\hline \multirow[t]{2}{*}{16} & Other diseases & 83 & 2,1 & - \\
\hline & Totally & 4013 & 100,0 & - \\
\hline
\end{tabular}

The diseases of mental and behavioral disorders are in the first rank-15.4\%; the second rank is disabilities caused by malignant neoplasms $13.1 \%$. The third rank is disabilities caused by the diseases of nervous system, the specific position of which is $12.0 \%$. Then disable people with circulatory system diseases take the fourth rank and their specific position is $10.7 \%$.

The disability caused by traumas, intoxication and some other consequences of external causes make up $8.1 \%$ th rank. The sixth rank is disabilities caused by digestive diseases, their share is $7.9 \%$.

Diseases of the musculoskeletal system and connective tissue account for $6.2 \%$, this contingent is ranked 7 th and the eighth rank is the disabilities caused by endocrine system diseases, nutritional disorders, metabolic disorders, the specific position of which is $5.5 \%$.
The ninth rank is the disabilities caused by diseases of eye and its appendages; their share is $4.5 \%$ of the total.

Next, the tenth rank is the disabilities caused by congenital malformations (deformities), deformations and chromosomal abnormalities; the specific position is $3.8 \%$ of the total.

The eleventh rank is the disabilities caused by tuberculosis diseases; the specific position is $2.8 \%$. Then the twelfth rank is the disabilities caused by diseases of genitourinary system, the proportion is $2.7 \%$.

The thirteenth rank is the disabilities caused by respiratory diseases, their specific proportion is $2.6 \%$ and the fourteenth rank is the disabilities caused by the diseases of ear and mastoid process and blood diseases, hemopoietic organs and individual disorders, their specific proportion is $1.0 \%$ of the total. 
Studying the structure of disability by severity shows the adversity with disabled people of the most severe levels - 1 and 2, correspondingly, 477 and $3228(11.9 \%$ and $80.4 \%)$. (Figure 2$)$.

\section{Figure 2. Distrubution of primary disability by severity level}

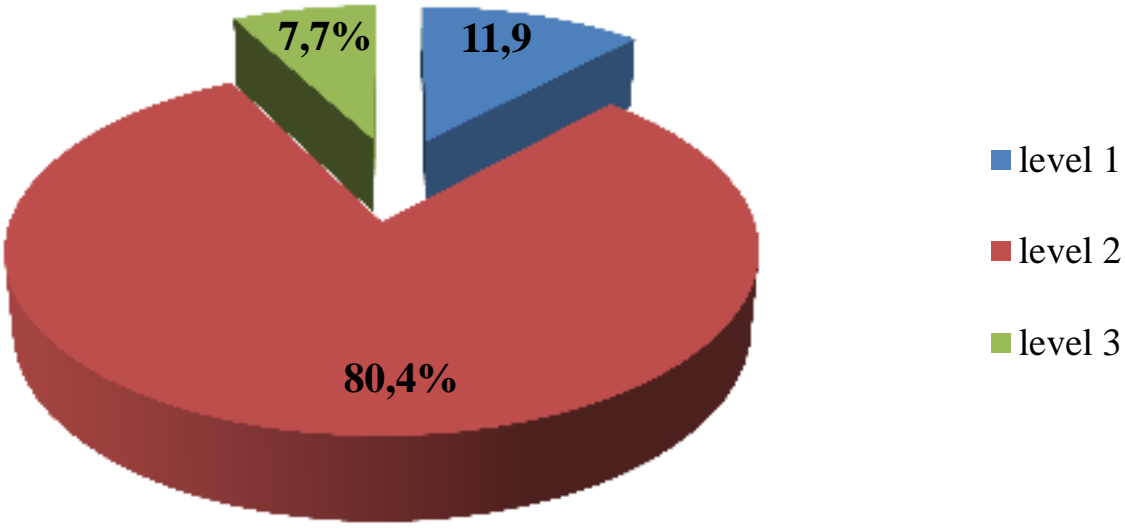

The above mentioned shows that the disability of employed population in Fergana region is an actual problem.

\section{CONCLUSIONS}

1. It was found that in the age group of 16-17, the number of primary disabled people is $562(12.9 \%)$, and in the age group of 18-19 there is a sharp decrease in the proportion of primary disabilities and ranks 70 people $(1.6 \%)$, then, in subsequent age groups, gradually increasing to $50-54$ years, the extensive disability rate reaches $14.9 \%$.

2. The analysis of the distribution of disabled people by class of diseases and the diseases caused to disability showed that more than half of the percent $(51.2 \%)$ in the structure was taken by disable people with mental and behavioral disorders, malignant neoplasms, diseases of circulatory system and nervous system.

3. The most adverse case is with disabled people of the most severe levels: group 1 and 2 , and this indicator makes $88.1 \%$ of all cases of disability.

\section{REFERENCES}

1. Gaykovich A.A. Medical and social problems of morbidity, disability and ways to improve the health care system of the population of the Lipetsk region // Abstract of the thesis work. Moscow. 2005. -42 p.

2. World Health Report 2000: Health Systems Improving Performance. WHO.- 2000. P.178184.

3. Lunaev V.P. The socio-hygienic basis of disability of the employable age population in
Russian Federation and the scientific fundamentals of developing integrated medical and social rehabilitation. - diss. thesis work. Moscow. 2007. P. 353.

4. Nemstsveridze E.Ya. Medical and social fundamentals of the formation the program for reducing the disability of the employable population at the territorial level .- diss. thesis work. Moscow. 2012. P. 285.

5. Puzin S.N., Lavrova D.I., Chikinova L.N. Disability prevention and rehabilitation development - priority tasks in the field of public health in Russia / Materials of the II Congress of the Russian Society of Specialists in Medical Social Expertise, Rehabilitation and Rehabilitation Industry. Moscow.2006. P. 1121.

6. Puzin S.N., Lavrova D.I. Medical and social expertise / S.N. Puzin, D.I. Lavrova - M .: MIA LLC. 2008. - 408 p.

7. Sayed Kammruzzaman, Lindenbraten A.L., Voronova N.E., Golovina S.M. Various methodological approaches to assessing economic losses from diseases (morbidity, disability, mortality) / J. Health Economics. 2009.Vol. 12. P-26-32.

8. Sayed Kamruzzaman. The scientific basis of the formation of programs for reducing mortality at the territorial level // Abstract of the diss. Moscow. 2011. 48-p. 